DOI https://doi.org/10.18551/rjoas.2018-09.61

\title{
THE FACTORS INFLUENCING PADDY LAND CONVERSION ON THE NON-PADDY LAND OF KLATEN DISTRICT, INDONESIA
}

\author{
Nurelawati Arisa*, Sutrisno Joko, Fajarningsih Rhina Uchyani \\ University of Sebelas Maret, Surakarta, Indonesia \\ *E-mail: arisanurelawati@gmail.com
}

\begin{abstract}
Land conversion is a change in the function of some parts or all of the land area from its original function to another function. The land conversion, somehow, can directly affect the environment and the inherent potential of the land. Land conversion is broadly conducted due to the growing needs of the population numbers. This research is done to reveal the factors that influence paddy land conversion to the non-paddy land in Klaten District, Indonesia. This research used analytic descriptive methods. The data used in this research are the secondary data by the year 2002-2016. The method of analyzing the data used the econometric analysis with the Ordinary Least Square model or multiple linear regression models. All selected data then computed by statistical software, Stata 12.0. The result of this study shows the factors that influence the paddy land conversion in Klaten District. They are the number of population, the number of industry, Gross Regional Domestic Product (GRDP) of agriculture, the land productivity, the average of paddy field area, and the average of education level. However, the most influential factors that influence the paddy land conversion are the number of industry, Gross Regional Domestic Product (GRDP) of agriculture, the average of paddy field area, and the average of education level. Meanwhile, the variables or factors that do not significantly influence the paddy land conversion in Klaten District are the number of population and the productivity land.
\end{abstract}

\section{KEY WORDS}

Land conversion, paddy field, multiple linier regressions, Klaten District.

Land is a natural resource that has primary function in developing the country. In the context of national growth, almost all the sectors require land such as agriculture, industry, trading, and also infrastructure sector. In agriculture sector, land is considered as a basic resource both for the farmers and the growth of agriculture itself. Indonesia is well known as an agricultural country which most of all the agriculture activities focus on the land. Land plays important role in the production activity which produces basic food need for all the people (Putri, 2015).

Mansur et al (2014) have presented that the areas of paddy fields have been declining due to the changes caused by the land conversion. The paddy field has important function as a media of paddy planting. Paddy becomes one of the important of agriculture commodities in human life. However, recently, a massive change happens in Indonesia in the context of agricultural land conversion. Agricultural land is gradually converted to non-agricultural land to extend human settlements and urban industrial area. This changing takes consideration to the economic feasibility. In this way, the government has to put into an action and require a change in the regulation and protection of farmers especially for the agricultural land which produces the livestock that all humans need. Unprotected agricultural land, somehow, will be vulnerable to the shifting functions, especially in the urban areas or growing cities.

According to (Hakim, 2002), an increase in economic growth will directly lead to the rapid growth in some part of economic sectors. Based on the result of empiric studies proposed by (Mustopa, 2011), the increase of economic growth will automatically involve the wider land so it will also increase the land requirement for developments of various sectors, particularly industry. The importance of land for various sectors, in fact, will increase the demand of the land use. However, there is a condition where the population growth is increasing but the land availability is relatively limited. Land availability as one of the 
production's factor, somehow, cannot be reproduced again by human because it belongs to non-produced input (Mubyarto, 1996).

Agriculture sector plays important role in contributing to the Gross Regional Domestic Product (GRDP) in Klaten District. Agriculture sector stands on the third rank after manufacturing sector, large or retail trade sector, and automotive sector. Agriculture sector, contributes a constant price at 2.814.072 (IDR) to the Gross Regional Domestic Product (GRDP) of Klaten District in 2016 (Badan Pusat Statistik Kabupaten Klaten, 2017). By this report, it indicates that agricultural sector becomes one of the pillars of the economic growth in Klaten District.

Klaten is one of the regencies of Indonesia which is expected to be the region that can support the national food security. It cannot be denied that Klaten has the fertile rice paddy and also adequate irrigation infrastructure. But, the industrial developments gradually change the agricultural land into the non-agricultural land for the shake economy feasibility. The paddy land conversion is happening then it directly gives negative impacts, because basically agricultural land has broad function both for economic, social, and environmental aspect. In the economic and social aspects, the paddy land conversion brings the hot issues and gives negative impacts to the farmer's life. It can reduce the agricultural employment and farmers' income in agriculture. Meanwhile, in the environmental aspect, a number of benefits of the land will be lost along with the loss of the function of the paddy fields that have been converted to the non-agricultural land (Budi, 2011). By this, the conversion of agricultural land is a threat to the achievement of food security and has serious implications for food production, the physical environment, and the welfare of agricultural and rural communities whose lives depend on their land.

The process of paddy land conversion to the non-paddy land for residential and industrial purposes, somehow, is difficult to be avoided as a result of population growth and rapid economic growth. The availability land is limited while the demand of the land requirement is increased significantly. It requires choice and reallocation of land use in the most economically profitable direction. Problems in agriculture, especially the paddy field in Klaten District, have been marked by the decrease of paddy field area because of the high level of paddy land conversion. By those explanations above, it need a further research to analyze the factors that may affect the paddy land conversion to the non-paddy land in Klaten District. It is conducted to build strategy to the land protection so that it will create an effective system for cultivating, managing, and controlling the paddy fields area in Klaten District.

The hypothesis of this research could be described as follow: the factors influencing the paddy land conversion in Klaten District were the number of population, the number of industry, Gross Regional Domestic Product (GRDP) of agriculture, the land productivity, the average of paddy field area, and the average of education level.

\section{MATERIALS AND METHODS OF RESEARCH}

This research used analytic descriptive methods. The method was used to know the factors influencing the paddy land conversion in Klaten District, Central Java Province, Indonesia. The data used in this research was the secondary data which included quantitative data from the year of 2002-2016. The data sources were Klaten central Bureau of Statistics, Klaten Development Planning Agency at Sub-National Level (Bapedda), Klaten District Agriculture Service, Klaten industrial services, the literatures such as books, journals, result of studies, and other supported data. Factors that supposed to influence the land conversion in Klaten District are as follows; the number of population, the number of industry or company, the Gross Regional Domestic Product of agriculture, land productivity, the average area of land ownership, and the average of education level.

The method of analyzing the data used the econometric analysis with the Ordinary Least Square method or multiple linear regression. All selected data then computed by statistical software, Stata 12.0. 
According to (Gujarati, 2006), formally, the equation of multiple linear regression model between variables can be formulated as follows:

$$
Y=\alpha+\beta_{1} X_{1}+\beta_{2} X_{2}+\beta_{3} X_{3}+\beta_{4} X_{4}+\beta_{5} X_{5}+\beta_{6} X_{6}+\varepsilon
$$

Where:

$Y=$ the loss of paddy field area because of the land conversion (ha);

$\alpha=$ the intercept;

$\mathrm{X}_{1}=$ number of population;

$\mathrm{X}_{2}=$ number of industry or company (in unit);

$\mathrm{X}_{3}=$ Gross Regional Domestic Product (GRDP) of agriculture in Klaten District (in million rupiahs);

$\mathrm{X}_{4}=$ the land productivity $(\mathrm{kw} / \mathrm{ha})$;

$\mathrm{X}_{5}=$ the average of land ownership (ha);

$\mathrm{X}_{6}=$ the average of education level (year);

$\beta \mathrm{i}=$ regression coefficient;

$\varepsilon=$ Error Term

The multiple linier regressions can be estimated by the ordinary least square methods (OLS). The basic concept of Ordinary Least Square model is to find the best fitting line or predict the regression coefficient $(\beta)$ by minimizing the error term/ $(\varepsilon)$. The Ordinary Least Square (OLS) assumption can be described as follows: (1) unbiased estimator and has minimum variance estimation both for linier or non-linier model (2) Consistent, sample size increase indefinitely, approaches the real value of the parameter in the population and (3) $\beta_{0}$ $\& \beta_{1}$ are normally distributed (Gujarati, 2006)

Model-based testing in this research was done to evaluate the accuracy and predictive power of regression models. There had been three model-based testing in this research; (1) Coefficient of determination (R-Squared) test, (2) the F-test for linier regression and (3) the T-test for linier regression.

The method of Classical assumptions test in this analysis of regression model was required to get the good model of linier regression and also to meet the BLUE criteria or generally called as Best Linear Unbiased Estimator. After the model was regressed then the assumption deviation tests were performed to check the model assumption. This included (1) multicollinearity test by using Pairwise Correlation Test, (2) heteroscedasticity test by using Breusch-Pagan Test, (3) normality test by using Shapiro-Wilk Test, and (4) autocorrelation test by using Durbin-Watson Test.

\section{RESULTS AND DISCUSSION}

A regional development is always related to the economic and population growth. Theoretically, the growth of a number of populations in a certain region will affect the demand of the land use. However, in fact, the availability of land today is limited. Recently, in Indonesia, there were resident's clashes due to land eviction and unclear land ownership. It is evoked by the program of land conversion, especially the paddy field which is converted into non-paddy field.

Klaten District becomes a region which continues to increase the economic development in its region. It will finally affect the paddy field area. The decline of the paddy field area in Klaten District can be seen at the Figure 1.

The Figure 1 shows the relative decline in the paddy field area by the year 2002- 2016. By the year 2002-2013, a significant decline of the paddy field area had occurred in Klaten District. Meanwhile, in the 2013 and the next year after that, the paddy field area remained the same. It means that there is no declination in the paddy field area at that time and it had the total area of 33.220 ha. However, in 2014-2016, the area had declined by 154 ha.

The paddy land conversion is always influenced by other variables. It means that the conversion does not take into an action by itself but it includes some factors that may influence the execution of paddy land conversion itself. The paddy land conversion in Klaten 
District can be influenced by total population in Klaten District, the number of industry or company, the Gross Regional Domestic Product (GRDP) of agriculture, the land productivity, the average of paddy field area, and the average of education level.

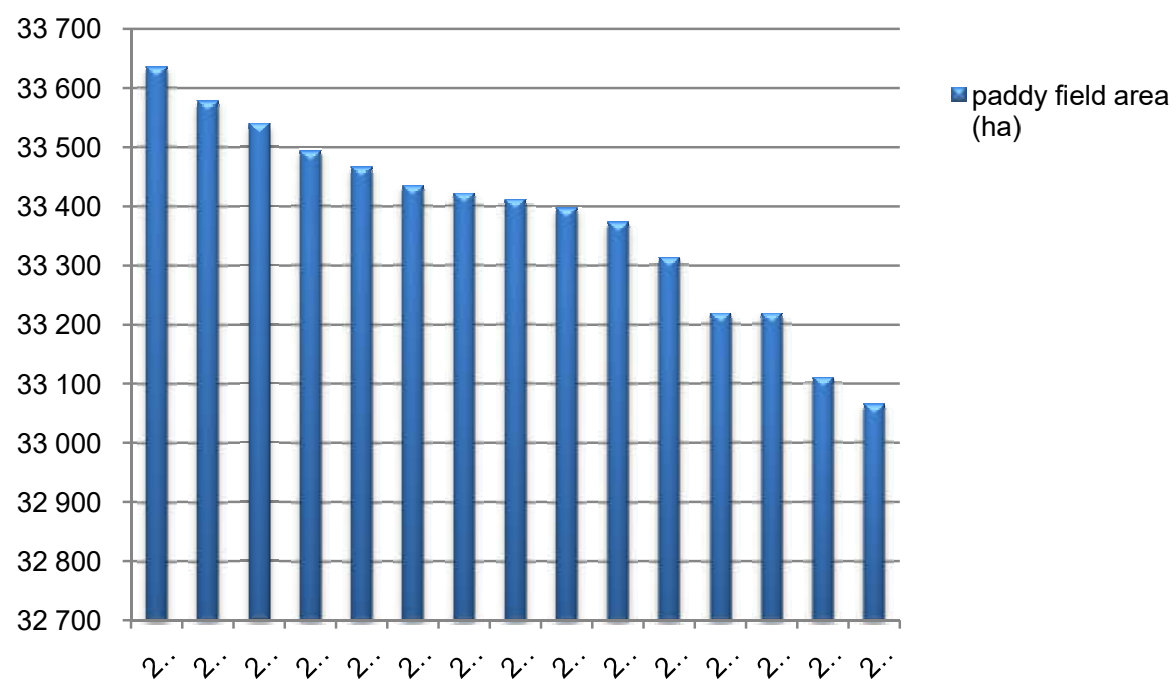

Figure 1 - Paddy field area in Klaten District by the year 2002 to 2016

To understand estimate factors which influence paddy field conversion in Klaten District, this research involved the econometrical analysis to meet the classical assumption of BLUE (Best Linier Unbiased Efficient Estimator) which includes multicollinearity test, heteroscedasticity test, normality test, and autocorrelation test. The result of the normality test with the Shapiro-Wilk Test shows that the error is normally distributed if the value is > 0.05. Symptoms of multicollinearity (Co-efficient of correlation between the independent variables is $\geq 0.8$ ) with the Pairwise Correlation Test appears when the variable of total population is included in the model. By this, the variable of total population needs to be transformed into transforming variables in the form of first difference. The heteroskedasticity test by using Breusch-Pagan Test, in this research, indicates the value which is more than 0.05 or $>0.05$. It means that it is free of heteroscedasticity. The others classical assumption test for this model of analysis are autocorrelation test by using Durbin-Watson Test with limited value of $\mathrm{dL}$ is 0.38897 while the limited value of $\mathrm{dU}$ is 2.57158 .

Table 1 - The results of the estimate factors which influence the paddy land conversion in Klaten District, Indonesia by the year 2002-2016

\begin{tabular}{llllll}
\hline No & Variable & Coef & Std.Err & $\mathrm{t}$ & $\mathrm{P}>[\mathrm{t}]$ \\
\hline & Constant & 375.2361 & 225.986 & 1.66 & 0.141 \\
1. & Number of Population & -0.0098462 & 0.0081 & -1.22 & $0.264^{\mathrm{ns}}$ \\
2. & Number of Industry & 0.2738647 & 0.0844106 & 3.24 & $0.014^{\star *}$ \\
3. & GRDP of agriculture & 0.0001136 & 0.0000354 & 3.21 & $0.015^{\star *}$ \\
4. & Land Productivity & -0.2789373 & 0.9606009 & -0.29 & $0.780^{\mathrm{ns}}$ \\
5. & Average of land ownership area & -0.0754167 & 0.0268908 & -2.80 & $0.026^{* *}$ \\
6. & Average of education level & -70.36712 & 30.43711 & -2.31 & $0.054^{*}$ \\
\hline & R-squared (R $\left.{ }^{2}\right)$ & & 0.7355 & & \\
& Adj R-squared & & 0.5088 & & \\
& Prob > F & & 0.0746 & & \\
& Breusch-Pagan test & & 0.9450 & & \\
& Shapiro-Wilk test & & 0.20064 & & \\
& Durbin-Watson test & & 2.572456 & & \\
& Sampling Period 2002-2016 (n) & & 14 & \\
\hline
\end{tabular}

Source: Analyzed by the Stata 12.0 (2018).

Notes: ${ }^{*}=$ significant at Confidence Interval of $90 \% ;{ }^{* *}=$ significant at Confidence Interval of $95 \%$; ns $=$ not significant. 
By evaluating the test, it can be produced the equation model of linier regression in the following pattern:

$$
Y=375.2361-0.0098 X_{1}+0.2738 X_{2}+0.0001 X_{3}-0.2789 X_{4}-0.0754 X_{5}-70.3671 X_{6}
$$

Based on the Table 1, the result of estimate value indicates a good fit. The coefficient of determination (R-Squared) is 0.7355 . This means the varieties that can be explained by explanatory factors in the model is equal to $73.55 \%$ while the others are explained by outside factors of the model. Meanwhile, the value of Adjusted R-squared is $50.88 \%$. Then, the value of F-statistic (Prob f-statistic) is 0.0746 or $7.46 \%$ which is smaller than the real level $(10 \%)$. This signifies that there is at least one independent variable that affects the dependent variable.

Based on the T-test of this linier regression, the result of the estimate value can be seen from the $p$ value/ significance. Based on the Table 1 , the probability value of $\left(X_{1}\right)$ is equal to 0.264 . Statistically, it does not significantly influence the paddy land conversion. In short, it can be described that the growth of population does not have a direct influence to the execution of land conversion in Klaten District. The variable of population $\left(\mathrm{X}_{1}\right)$ however, is not significant with hypothesis of this research. In the beginning, it is stated that the variable of population will bring significant effect to the land conversion. Moreover, the growths of population will loss the land area of the paddy field because of the high demand of the land requirement for industrial or residential purposes. However, the result of the study shows that the variable of population $\left(\mathrm{X}_{1}\right)$ does not contribute to the paddy land conversion. This means that a residential construction is not only executed in the paddy land but also in the nonpaddy land. In this highlight, this research is not in accordance with the research done by Haarsma \& Qiu (2017) and Azadi et al (2011). Both of the researches have declared that the paddy land conversion is executed because of the growth population.

The variable of number of industry $\left(X_{2}\right)$ indicates the $p$-value/significance is equal to 0.2738647 . This means that this result is significant at the Confidence Interval of $95 \%$. This shows that there is a positive influence between land conversion and the number of industries in Klaten District. If the number of industries increases, then the land requirement for industrial also increases. There is an indication that the area of agriculture will be converted into industry if the number of industries is increasing. This research is in accordance with the research done by Kustiawan (1997). In the macro perspective, the phenomenon of agricultural land conversion in developed country is caused by the economic structural transformation and the demographic condition of the country. The economic structural transformation means that there is a transformation of economic pillar from the agricultural sector to the industrial sector. Meanwhile, Fauzi (1992) in his research has described that the agricultural land conversion is influenced by the growth of population, nonagriculture household, the distance and location of the land which is near with the area of industry. In addition, this research is also supported by a study done by Prajanti (2014) in some part of the region in Central Java province, Indonesia. She found that there were many residential and industrial area which exist in the agricultural land which have been successfully converted into non-agricultural land. Different location, a research done by Phuc et al (2014) in Hue, Vietname, has showed that the land conversion is for increasing the number of industry and developing the town. It goes hand in hand with the hypothesis of this research which shows the development of industry will increasingly raise the phenomenon of land conversion in Klaten District.

Based on the Table 1, the variable $\left(\mathrm{X}_{3}\right)$ or Gross Regional Domestic Product (GRDP) statistically influences the land conversion in Klaten District. It is indicated by the result of the analysis which is significant at the Confidence Interval of $95 \%$ with the probability value 0.015. It means that GRDP or Gross Regional Domestic Product gives significant influence in conducting the land conversion in Klaten District. The GRDP is one of the indicators that can describe the economic growth. An increase in economic growth in a certain region can rapidly change the economic structure into manufacturer sector. The development of manufacturer sector and other sectors that require land use, somehow, become one of the 
causes of the paddy land declination in Klaten District. This result of this analysis is in accordance with the research done by Pakpahan and Anwar (1989). The research was conducted in West Sumatra province, and South Sulawesi province, Indonesia. They have successfully examined the factors influencing the land conversion in both of the provinces. It is said that the land conversion is influenced by the economic growth which is not accompanied by the increased value of food crops. Meanwhile, the research done in West Java Province, Indonesia, shows that the factors influencing the conversion of the paddy land to the non-paddy land are the economic growth in the non-agricultural sector, the number of population, the location of the land from Central Business District (CBD) (Hakim, 1989). This means that getting closer to the CBD area, the conversion rate is indicative high. This result is also supported by the research done by Schmitz et al (2014) in South America and Sub-Saharan Africa and also Zhang et al (2014) in Zhejiang, China. The results from previous researches are clearly stated in accordance with this research. Those support the research hypothesis in this research.

Based on the Table 1, the variable of land productivity $\left(X_{4}\right)$ has negative result but it does not significantly influence the paddy land conversion. The probability value is equal to 0.780 , greater than the real level of 10 percent $(0.780>0.1)$. It can be interpreted that the land productivity does not necessarily cause the paddy land conversion in Klaten District. It is because there are neighborhood and citizens associations in Klaten District which regulate the land allotment as sustainable paddy fields which makes those fields cannot be converted even they have low productivity of the land. A research done by Laksamana (2015) has described that the land productivity does not have direct impact to the decline of the paddy fields area. The factors that cause the agricultural land conversion in the macro level are the number of residence and industry. However, a research done by Amalia (2014) has indicated the contradictory result with this research. It was stated that the increased of land productivity will maintain the existing area of paddy fields. By this research, it indicates that the paddy land conversion occurs only in the paddy fields which have low productivity. The low productivity of land is caused by some factors such as texture of soil that is difficult to plant, poor irrigation, or excessive use of chemicals. The owner of the lands, somehow, will be interested to sell the paddy fields to the investors. That will be more profitable than doing the farm by themselves. Such condition contributes to the indication of paddy land conversion into non-paddy land.

The variable of average area of land ownership $\left(\mathrm{X}_{5}\right)$ signifies the P-value which has negative value of -0.0754167 . It is significant at the Confidence Interval of $95 \%$. By this result, it can be said that the wider area of paddy land ownership can reduce the occurrence of the paddy land conversion. The farmers who have wider area of the paddy land will be interested to choose maintaining the land to get its benefits especially for the fertile lands. The fertile lands can increase the land productivity so that the farmers' income will automatically increase. This is in line with the result of the study done by Barokah et al (2003) in Karanganyar District, Central Java Province, Indonesia. It is already stated in their research that the wider land area will increase the contribution of income from farming both in the region that is far from the center of economy or not. This result of study shows that the farmer's household prefers to continue to pursue their farming as long as they have wider land ownership. In this light, the final result of this research is stated in accordance with previous research and this result of study also supports the research hypothesis.

Based on the Table 1, the result of the average of education level $\left(\mathrm{X}_{6}\right)$ significantly influences the execution of the paddy land conversion in Klaten District. The probability value is 0.054 and it is significant at Confidence Interval $90 \%$. The parameter of coefficient $X_{6}$ shows the negative value; -70.36712 . It can be said that the longer education is taken; the opportunities for farmers to shift the function of the land are smaller. The length of education shows someone educational attainment. The higher education level will bring impact to the land conversion which means the higher education level will reduce the program of land conversion. For those who have higher education level, of course, will require hundreds of consideration to get involved in the land conversion because they have good rationality. In addition, the farmers, somehow, will choose to not to get involved in the paddy land 
conversion because they will find difficulties to get new jobs which appropriate with them. Basically, the paddy land conversion is highly correlated with the income received by farmers.

\section{CONCLUSION AND SUGGESTIONS}

Based on this research, it can be concluded that the factors influencing the paddy land conversion in Klaten District are the number of population, the number of industry, Gross Regional Domestic Program of agriculture, the land productivity, the average of paddy field area, and the average of education level. The most influential factors which cause the paddy land conversion are the number of industry, Gross Regional Domestic Program of agriculture, the average of paddy field area, and the average of education level. Meanwhile, the variables that do not significantly cause the paddy land conversion in Klaten District are the number of population and the productivity land. Based on this research, it is suggested to the government to take a consideration toward the issue of the decline of paddy land area because of the land conversion for some purposes. It needs resolute punishment and requires government regulation to protect the land use from residential and industrial purposes.

\section{REFERENCES}

1. Amalia, S. N. (2014). Analisis Dampak Ekonomi dari Alih Fungsi Lahan Pertanian ke Non Pertanian terhadap Ketahanan Pangan di Kabupaten Bogor. Institut Pertanian Bogor. Bogor.

2. Azadi, H., Ho, P., \& Hasfiati, L. (2011). Agricultural land conversion drivers: A comparison between less developed, developing and developed countries. Land Degradation and Development, 22(6), 596-604. https://doi.org/10.1002/ldr.1037

3. Badan Pusat Statistik Kabupaten Klaten. (2017). Klaten dalam Angka 2017. Retrieved from http://www.klatenkab.bps.go.id

4. Barokah, U., Supardi, S., \& Handayani, S. M. (2003). Pendapatan Rumah Tangga Petani di Kabupaten Karanganyar. Artikel Konversi KPPMF. Universitas Sebelas Maret. Surakarta.

5. Budi, T. S. (2011). Faktor-Faktor Yang Mempengaruhi Konversi Lahan Pertanian Ke Non pertanian di Kabupaten Sragen Tahun 1990-2009. Universitas Sebelas Maret. Surakarta.

6. Fauzi. (1992). Perubahan Penggunaan Lahan Pertanian di Daerah Pinggiran Kota (Studi Kasus di Kabupaten Bogor, Tangerang, dan Bekasi). Institut Pertanian Bogor. Bogor.

7. Gujarati, D. (2006). Dasar-dasar Ekonometrika Edisi Ketiga (3rd ed.). Jakarta: Erlangga.

8. Haarsma, D., \& Qiu, F. (2017). Assessing Neighbor and Population Growth Influences on Agricultural Land Conversion. Applied Spatial Analysis and Policy Journal, 10(1), 21-41. https://doi.org/doi.org/10.1007/s12061-015-9172-0

9. Hakim, A. (2002). Ekonomi Pembangunan (Pertama). Yogyakarta: Ekonisia.

10. Hakim, C. (1989). Perubahan Penggunaan Tanah Pertanian ke Penggunaan Tanah Non Pertanian. Institut Pertanian Bogor. Bogor.

11. Kustiawan, I. (1997). Alih Fungsi Lahan Pertanian di Pantai Utara Jawa. PRISMA, 26(1), 15-32.

12. Laksamana, R. (2015). Analisis Dampak Alih Fungsi Lahan Pertanian Terhadap Kemandirian Pangan di Kabupaten Subang. Institut Pertanian Bogor. Bogor.

13. Mansur, Y. H., Soetarto, E., \& Gandasasmita, K. (2014). Pola Konversi Lahan dan Strategi Perlindungan Lahan Sawah di Kota Sukabumi. Jurnal Sumber Daya Lahan, 8(2), 109-123.

14. Mubyarto. (1996). Pengantar Ekonomi Pertanian (Ketiga). Jakarta: LP3ES.

15. Mustopa, Z. (2011). Analisis Faktor-Faktor yang Mempengaruhi Alih Fungsi Lahan Pertanian di Kabupaten Demak. Universitas Diponegoro, Semarang.

16. Pakpahan, A., \& Affendi Anwar. (1989). Faktor-Faktor yang Mempengaruhi Konversi Lahan Sawah. Jurnal Agro Ekonomi, 9(8), 62-74. 
17. Phuc, N. Q., Westen, A. C. M. van, \& Zoomers, A. (2014). Agricultural land for urban development: The process of land conversion in Central Vietnam. Habitat International Journal, 41, 1-7. https://doi.org/10.1016/j.habitatint.2013.06.004

18. Prajanti, S. D. W. (2014). Strategy for controlling agricultural land conversion of paddy by using analytical hierarchy process in Central Java. Management of Environmental Quality: An International Journal, 25(5), 631-647. https://doi.org/10.1108/MEQ-07-20130080

19. Putri, Z. R. (2015). Analisis Penyebab Alih Fungsi Lahan Pertanian Ke Lahan Non Pertanian Kabupaten/Kota di Provinsi Jawa Tengah 2003-2013. Eko-Regional, 10(1), 17-22.

20. Schmitz, C., van Meijl, H., Kyle, P., Nelson, G. C., Fujimori, S., Gurgel, A., Havlik, P., Heyhoe, E., d'Croz, D. M., Popp, A., Sands, R., Tabeau, A., van der Mensbrugghe, D., von Lampe, M., Wise, M., Blanc, E., Hasegawa, T., Kavallari, A., H. (2014). Land-use change trajectories up to 2050: insights from a global agro-economic model comparison. Agricultural Economics, 45, 69-84. https://doi.org/10.1111/agec.12090

21. Zhang, W., Wang, W., Li, X., \& Ye, F. (2014). Economic development and farmland protection: An assessment of rewarded land conversion quotas trading in Zhejiang, China. Land Use Policy Journal, 38, 467-476. 